\title{
МЕЖДУНАРОДНАЯ ПРАВОСУБЪЕКТНОСТЬ, ПРИНЦИП GENERALITAS И ПОЛИТИЧЕСКИЕ ТРАДИЦИИ В КОДИФИКАЦИОННЫХ АКТАХ ЮСТИНИАНА (527-565 ГГ.): НОВЫЕ ИССЛЕДОВАТЕЛЬСКИЕ ПОДХОДЫ
}

Мельник В. М.

Научная статья посвящена важной проблеме византийской юридической истории - принципам кодификации римского права в VI веке н. э. Исследовано использование чиновниками Юстиниана Великого принципов generalitas, источники leges, правовой статус Прагматических санкций. Впервые предложено разделение византийской теории международного права на две части - т. н. субъективную и объективную линии. Разграничены международно-правовые понятия «идеальная реальность» и «военно-политическая реальность».

Ключевые слова: идеальная реальность, военно-политическая реальность, Восточная Римская империя (Византия), римское публичное право, generalitas, leges, Corpus Juris Civilis.

Наукова стаття присвячена важливій проблемі візантійської юридичної історії - принципам кодифікації римського права. Досліджено використання чиновниками Юстиніана Великого принципів generalitas, джерела leges, правовий статус Прагматичних санкцій. Bперше запропоновано поділити візантійську теорію міжнародного права на дві частини - суб'єктивну та об'єктивну лінії. Розмежовано міжнародно-правові поняття «ідеальна реальність» та «військово-політична реальність».

Ключові слова: ідеальна реальність, військово-політична реальність, Східна Римська імперія (Візантія), римське публічне право, generalitas, leges, Corpus Juris Civilis.

The scientific article is devoted to the important problem of Byzantine legal history - to the principles of the codification of Roman law in the VI century AD. The use by officials of Justinian the principles by generalitas, sources of leges, and the legal status of Pragmatic sanctions was investigated. For the first time proposed the division of the Byzantine theory of international law into two parts - subjective and objective lines. The international legal concepts "ideal reality" and "military-political reality" are delimited.

The Imperial Commission, headed by Justinian, of eight officials and two Constantinople lawyers, acted on the principle of pragmatism and practicality. Every imperial law announced hitherto was freed from rhetorical reasoning and philosophical preambles. Justinian's commission focused on the method of creating generalitas - the legal principle of importance. The code was supposed to level the significance of the individual rulings of the emperors (relating to a particular court case) and summarize all possible decisions in all possible cases.

Compiling the texts of the imperial laws, members of the commission, with the permission of Justinian, actively edited the direct speech of the former emperors. Occurred de-philosophization existing law. Texts were supposed to be as practical and easy to use for all citizens of the Empire. In this respect, the reform of Justinian, of course, had a significant social orientation. Now, each person could understand the essence of his own rights and obligations without consulting a costly legal adviser. To comprehend civil legal wisdom, it was now not necessary to have a philosophical education. It was a revolutionary decision, which, moreover, was accompanied by the development of principles of consistency in the theory of law. A sign of consistency was the division of all types of court cases into sections that corresponded to the main areas of social activity.

Key words: Ideal Reality, Military-Political Reality, Eastern Roman Empire (Byzantium), Roman Public Law, Generalitas, Leges, Corpus Juris Civilis.

Постановка проблемы и ее актуальность. Процесс восстановления византийцами политического контроля над западными римскими провинциями (533-560 гг.) совпал по времени с масштабной правовой реформой [7, с. 391-393]. Характеризуя систематизацию и кодификацию римского права, осуществленную Юстинианом Великим (527-565), д-р Питер Хизер подчеркивает: «долгосрочные последствия этого проекта вряд ли могли бы быть больше. По сути, реформа путем составления свода законов сохранила тщательно сделанную выборку из римской юриспруденции за тысячелетие. Это было сделано так методично, что итоговый текст - Corpus luris Civilis или «Свод гражданских законов» - стал всеобъемлющим образцом вместе с многочисленными отдельными частями законодательства для многих развивающихся судебных систем Центральной и Западной Европы, начиная со Средневековья и заканчивая началом современного периода. Поэтому именно благодаря Юстиниану изучение римского права остается главной частью университетских курсов юриспруденции» [12, с. 156].

Действительно, П. Хизер прав. Представить себе правовую систему любого европейского государства (да и многих азиатских стран) без систематизации Юстиниана невозможно. Само понятие юридической системности было разработано во времена Юстиниана. До 527 2. право характеризовалось бессистемной отрывочностью [12]. Можно говорить о попытках системного изложения правовых норм, предпринятых в ряде древних государств и Древнем Риме. Однако, ни одна из них не прижилась в таком масштабе, как кодификация Юстиниана Великого. Пожалуй, все византинисты должны гордиться тем, что понятия «верховенства права» и «правового государства» происходят из Восточной Римской (Византийской) империи VI века.

Цель статьи - введение в отечественный научный обиход новых подходов к исследованию феномена кодификации римского права византийским императором Юстинианом. Статья анализирует теорию международной правосубъектности, отраженную в Corpus Juris 
Civilis; использование принципа generalitas; соотношение между generalitas, вызовами исторической действительности и общепринятыми политическими традициями. Для удобства читателей, основной материал разбит на соответствующие пункты.

Объективная и субъективная линии византийской теории международного права.

Благодаря Кодексу Юстиниана мы, например, можем сделать вывод о юридическом статусе Италии - византийской провинции [C. J., VI, 51 pr.]. Опираясь на образцы систематизации, мы можем проследить трансформацию византийского мировоззрения в отношении понятий «государство», «независимость государства», «суверенитет», «внешняя война», «внутренняя война» [7, с. 391-395]. Полученных данных вполне достаточно для того, чтобы судить о международно-правовой теории Византии [8, с. 59-92]. В этом контексте, необходимо разграничивать два вектора теоретического развития международного права - объективный и субъективный.

Объективная линия теории международного права состояла в том, что реально в позднеантичном мире существовало лишь одно истинно Римское государство - Византийская империя. Поскольку это была единственная христианская империя, она претендовала на вселенскую власть, основываясь на двух идеологических догмах:

а) византийцы были наследниками и продолжателями имперской политической традиции Древнего Рима;

б) византийцы были носителями идей и практики Слова Божьего - христианами.

Переплетение имперской и христианской традиций делало византийское законодательство потенциальным сводом законов для народов всех стран и территорий. Дальнейшее развитие теории симфонии и становление византийской философии показывает, что любой христианин в любой части света де-юре считался подданным византийского императора [7, с. 391]. Такие принципы юридического мировоззрения и правовой культуры никоим образом не мешали утверждению субъективной линии развития теории международного права.

Да, византийцы понимали, что существует определенная идеальная реальность - в мире есть одно христианское государство во главе с одним христианским императором. И это государство (Восточная Римская империя) потенциально должно охватить всех христиан на свете. Оно выполняет функцию центра и притягательной силы для каждого христианина. Но военно-политические реалии сложились таким образом, что Восточная Римская империя не могла существовать без дипломатии, лавируя между различными внутренними и внешними силами.

В христианском мире, где моральный, религиозный и юридический авторитет Византии, базировавшийся на христианской и римско-императорской политических традициях, не подвергался сомнениям, во времена поздней античности, была найдена компромиссная форма фактического признания существующих политических структур. В отношении варварских королевств (Бражского королевства свевов, Тулузского/Толедского королевства вестготов, Лионского королевства бургундов, Карфагенского королевства вандало-алан, Равеннского королевства остготов) этот компромисс очевиден уже во времена, предшествовавшие восшествию Юстиниана Великого на престол $[7 ; 8 ; 12]$.

В 476-527 гг. варварские королевства, на основании заключенных ранее (еще западными римскими императорами) договоров о предоставлении права foedus, признавали верховную власть императоров Восточной Римской империи, а благодарные императоры не вмешивались во внутриполитические процессы на землях западных провинций $[2 ; 4 ; 11]$. Такое положение вещей, в принципе, устраивало все стороны. Собственно, из взаимодействия «император-федераты», выросла субъективная линия развития международного права, согласно с которой, варвары-федераты считали себя независимыми образованиями (традиционно признающими верховную власть императора - главы христианского мира и наследника древних европейских властителей), а византийцы рассматривали их как составную часть собственной империи [11, с. 62-66]. С точки зрения византийцев, варвары не могли быть независимыми по своему определению («идеальная реальность»). В то же время, варвары подчинялись императорской власти только юридически, оставляя фактическое руководство в свочх руках («военно-политическая реальность»).

Другой стороной субъективной линии развития международного права в V - VII вв. являлось политико-правовое признание существования другой империи - Персидской. Для византийских источников характерно осмысление самих себя некой избранной и мессианской организацией - единственной христианской империей, призванной объединить всех людей вокруг идеи Спасения. При всем этом философствовании, как в случае с варварами-федератами на Западе, византийцы признавали фактическое положение вещей - наличие других правовых и религиозно-политических структур. К примеру, Византийская империя однозначно признавала Персию [1; 9].

В то время Сасанидский Иран являлся очень могущественным государственным образованием. Он часто сталкивался с теми же проблемами, что и Восточная Римская империя - варварские набеги, внутренние неурядицы, возвышение варваров-кочевников. Персию и Византию связывали не только многовековые конфликты, но и общность имперской политической судьбы. Историческое сравнение условий формирования и укрепления императорской власти персов и римлян (как восточных, так и западных), позволяло византийцам признавать право Персии на мощь и силу. Поскольку, ни греки, ни римляне так никогда и не смогли полностью победить Персию, византийцы были вынуждены считаться с персидским имперским статусом. Персия признавалась империей (хотя, конечно, не равнозначной христианской Восточной Римской империи). Благодаря этому признанию, отношения восточных римлян с иранским шахиншахом имели все признаки международно-правового регулирования.

В сказанном состоит принцип субъективной линии развития международного права - каждая сторона рассматривала международные (межгосударственные) отношения с присущих ей мировоззренческих позиций. Если для варваров важна политическая u хозяйственная независимость, то для византийцев важно было сохранить императорский 
престиж путем использования юридических формулировок и традиционных процедур. Византийские императоры давали варварам, во многих случаях, неограниченную свободу политических действий, в обмен на признание своих высших позиций. Все стороны действовали субъективно.

Не менее субъективными представляются отношения между персами и византийцами. Для каждой империи (и тогда, и в новейшие времена) характерно признание собственного величия и политико-правового примата. Сасанидская Персия не была исключением. Безусловно, персы, основываясь на традициях и успехах своего существования, не могли считать римлян (как западных, так и восточных) главными. Внутри они также отбрасывали равенство, рассматривая все народы вокруг (византийцев также) в качестве потенциальных подданных. Но поскольку ни одна из сторон за много веков не смогла добиться решающего перевеса, Персидская и Византийская империя пришли к взаимному признанию. Это также был компромисс. Ведь мировоззрение тех и других базировалось на духовном превосходстве. Соответственно, взаимное юридическое признание - практический компромисс, призванный урегулировать политическое общение.

В духовной сфере (в мире идеальных представлений) византийцы и персы все равно оставались на своих мировоззренческих позициях. В этой культурной черте субъективизма содержится очень важный принцип для дальнейшей истории международного права - установление прагматического компромисса между различными субъективностями. Кодификация восточноримского законодательства Юстинианом базировалось на принципах субъективизма.

Принцип generalitas и дефилософизация права.

1 августа 527 г. Юстиниан Великий занял место своего дяди Юстина І. Уже через полгода, 13 февраля 528 г., новый император анонсировал начало большой юридической реформы. Она должна была, наконец, упорядочить судебные процедуры и деятельность правовых институтов. К тому времени, в деятельности судебных инстанций начался кризис источников. Количество судебных дел постоянно увеличивалось, а существующие источники, по которым судьи определяли степень и меру ответственности или процессуальную принадлежность дела, перестали отвечать запросам времени. Предыдущая кодификация императора Феодосия II Законодателя (408-450) не была достаточно объемной и глубокой. Ее поверхностность в гражданских вопросах оставляла такое количество лазеек для разнообразных трактовок конкретных предписаний, что деятельность адвоката вынужденно сравнивалась с риторической эквилибристикой. Кроме того, многочисленность трактовок открывала новые возможности перед личным обогащением судей и чиновников [10].

Византийские суды, вынося соответствующее решение, базировались на двух видах источников.

Первый вид источников - работы юристов и философов, на которые в прошлом, в собственных документах, ссылались римские императоры.

Второй вид источников - судебные решения, указы и постановления римских императоров.

Ссылаясь на указы и постановления римских императоров, суды должны были считаться с тем фактом, что императоры были физически не в состоянии регу- лировать все возможные случаи частных и публичных споров [1; 2; 10; 12]. Суд принимал во внимание определенную императорскую норму, регулирующую конкретное дело, и, на основании этой нормы, составлял схему решения нового дела.

В 520-х гг. созрела необходимость создания единой схемы решения для разных дел, классифицированных по типам. Юстиниан поставил перед собой две задачи - схематизацию и типологизацию судебной практики. К решению поставленных задач правительство приступило через подготовку нового учебника, который должен был основываться на Институциях юриста Гая (III в.).

В процессе формирования доктрины учебника были выявлены существенные прорехи в системе римского гражданского права. Уже в феврале 528 г. Юстиниан предписал своей администрации скомпилировать полное собрание римских законов, ориентируясь на три попытки кодификации - Кодекс Феодосия (438 г.) и Кодексы Гермогениана и Григориана (290-е гг.). Если Гермогениан и Григориан собрали в своих Кодексах имперское законодательство от начала Империи до 130-х гг. (эпохи принципата), то Феодосий II свел воедино имперские законы 300-438 гг. (эпохи домината).

Императорская комиссия, возглавляемая Юстинианом, из восьми чиновников и двух константинопольских адвокатов, действовала по принципу прагматичности и практичности. Каждый объявленный доселе императорский закон освобождался от риторических рассуждений и философских преамбул. Он очищался до чистой схемы диспозиции и развязки дела. Комиссия Юстиниана ориентировалась на метод создания generalitas - юридического принципа общей важности. Кодекс должен был нивелировать значение индивидуальных постановлений императоров (относящихся к конкретному судебному случаю) и обобщить все возможные решения во всех возможных случаях [12].

Компилируя тексты императорских законов, члены комиссии, с позволения Юстиниана, активно редактировали прямую речь бывших императоров. Происходила дефилософизация действующего права. Тексты должны были стать максимально практичными и простыми в использовании для всех граждан Империи. В этом отношении, реформа Юстиниана, конечно, имела значительную социальную направленность. Теперь каждый человек мог сам разобраться в сущности собственных прав и обязанностей, не обращаясь за консультацией к дорогостоящим юрисконсультам. Для постижения гражданской юридической премудрости теперь было необязательно обладать философским образованием. Это было революционное решение, которое, к тому же, сопровождалось выработкой принципов системности в теории права.

Признаком системности стало разделение всех типов судебных дел на разделы, которые соответствовали главным сферам социальной жизнедеятельности. В итоге, существенно измененные тексты бывших императоров «выстраивались под тематическими заголовками в пронумерованных книгах в хронологическом порядке в рамках отдельных глав» [12, с. 160]. Главной проблемой стал вопрос - что из текстов трех Кодексов вырезать, а что оставить; каким образом совместить старые законы с новыми постановлениями 
Юстина I и Юстиниана I? Несмотря на многочисленные трудности текстологического характера, 7 апреля 529 года Юстиниан Великий опубликовал собственный первый Кодекс.

Большой удачей считался тот факт, что, к примеру, комиссия Феодосия II Законодателя работала целых девять лет над своим Кодексом (438 г.), в то время как комиссия Юстиниана справилась в течение года. Теперь Византийская империя обладала кодифицированным законодательством, базированным на совершенно новом принциne generalitas. Состоялось письменное закрепление примата общего над частным.

Новое определение юриспруденции.

Публикация Кодекса стала первым шагом к подготовке нового проекта - созданию системы юридических формулировок. Она обнаружила существенную недостачу точных определений. Понимая, что для любого судебного или административного разбирательства важна точность формулировок, Юстиниан назначил новую комиссию, во главе с квестором Трибонианом. Это учреждение должно было разработать 50-книжный текст под названием «Дигесты» («Пандекты») - «первую попытку оформить труды юристов в методическую систему» [10, с. 73].

Огромная подготовительная работа, проведенная во время написания Кодекса Юстиниана (529 г.) позволила существенно модифицировать принцип generalitas. O его теоретическом содержании публично заявил Юстиниан, издавший 15 декабря 530 г. постановление Deo Auctore («Божьей властью»).

Процитируем постановление: «Ничто ни в какой сфере так не достойно изучения, как власть закона, который приводит в порядок дела как божественные, так и человеческие и изгоняет всякую несправедливость... Поэтому мы повелеваем вам (обращаясь к Комиссии квестора Трибониана - В. М.) читать и работать над книгами, связанными с римским правом, написанными теми учеными людьми давних времен, которым самые почитаемые императоры давали полномочия писать и толковать, чтобы из них можно было извлечь всю суть, а все повторения и противоречия были бы по возможности устранены, и из них можно было бы составить одно сочинение, которого было бы достаточно вместо них всех... чтобы ничто не могло остаться не включенным в законченный труд... Но чтобы в этих пятидесяти книгах все древние законы - в запутанном состоянии на протяжении почти четырнадцати сотен лет, что было исправлено нами, - были бы словно защищены стеной и чтобы ничто не осталось не охваченным ими. Все авторы законов будут иметь равный вес, и ни у кого из них не будет превосходства над другими, так как не все считаются лучше или хуже во всех отношениях, а только некоторые в отдельных отношениях» [Deo Auctore, 1 ; 4-5].

Руководствуясь принципом generalitas, Комиссия Трибониана прочитала две тысячи специальных сочинений, состоящих из трех миллионов строк. Реализация императорского указания состояла в сокращении числа книг - с двух тысяч до пятидесяти. С этим Комиссии удалось справиться. До сих пор выглядит удивительной трудоспособность чиновников и трудоемкость процесса. Ведь все адвокаты и юрисконсульты Империи трактовали разные нормы по-разному. Между ними также не было согласия в оценке доктринальной важности того или иного философа-юриста древности. Об этом пишет Питер Хизер: «Римское право было джунглями, тиграми в котором считались адвокаты, а самые хорошие из них - кто лучше всего подгонял мнение юрисконсульта и императорской власти к нуждам своих клиентов - получали астрономические гонорары» [12, с. 162-163]. Чтобы успешно реализовать реформу, Юстиниану пришлось заручиться поддержкой ряда известных и влиятельных адвокатов. Но, получая поддержку от одних, он тотчас же становился врагом для других. Решение проблемы Комиссия Трибониана нашла в открытой поддержке одной части правоведов, соединенной с давлением на другую часть. Прежде всего, Юстиниан наградил исключительными полномочиями и почестями выпускников двух юридических школ Константинопольской и Бейрутской. Кроме этих двух школ, на землях Византии, существовали также юридические учебные заведения в Александрии и Кесарии. Их закрыли. Соответственно, Юстиниан предоставил Бейруту и Константинополю возможность разделить имперский рынок юридических услуг, уменьшив конкуренцию вдвое.

Дигесты Юстиниана были утверждены императором 16 декабря 533 года. По своему масштабу этот документ не имел равных. «Вмещая все» (перевод с греческого слова «Пандекты»), Дигесты предлагали системное изложение мнений 39 знаменитых древних римских юристов. Хотя данному вопросу посвящено огромное количество литературы, мы позволим себе подчеркнуть, что Дигесты обосновали понятие логики правового действия. «Главной целью второго этапа законодательной реформы были сокращение юридического материала, ликвидация лишнего, повторений и, прежде всего, противоречий» $[12$, с. 170].

Юриспруденция впервые рассматривалась как целостное учение о человеке и обществе. Основываясь на мысли Ульпиана, Дигесты определяли: «Юриспруденция - это познание Божественных и человеческих дел, знание справедливого и несправедливого» [Dig., 1.1.10]. Дигесты тематически распределяли взгляды ученых на правовое регулирование конкретных сфер человеческой жизнедеятельности. Для теории международного права наибольшее значение имеет первая книга, рассматривающая «общие понятия, историю источников права, учреждения и лица с их правоспособностью и дееспособностью» [3, с. 215].

Учебник-закон и система права.

Вплоть до 533 г. Комиссия Трибониана вела активную работу над подготовкой учебника «Институции» (с латинского буквально - «Руководство»). Следуя договоренности с константинопольскими и бейрутскими адвокатами, Трибониан ориентировался на советы и правовую практику ближневосточных юристов. В процессе подготовки учебника ему помогали профессоры права Феофил и Дорофей. 21 ноября 533 г. написание «Институций» было окончено, а уже 30 декабря 533 г. Юстиниан провозгласил «Институции» официальным законом Империи. Таким образом, Институции стали первым и последним образовательным учебником, получившим статус действующего права. Все рекомендации и методика проведения судебных разбирательств, описанные в «Институциях», должны были с этого момента применяться каждым судьей, чиновником и адвокатом. 
Следует подчеркнуть, что придание официального статуса «Дигестам» и «Институциям» со стороны Юстиниана Великого, повлияло на коренные перемены внутри византийской адвокатуры. C 533 г. институт адвокатуры перешел в систему государственной служебной структуры, которая в своих действиях должна была руководствоваться конкретными предписаниями, а не толкованиями.

16 декабря 533 г. Constitutio Tanta, как особый закон Юстиниана, подтверждающий статус «Дигест», провозгласила: «Случись так, что в том или ином месте в таком большом сборнике юридических норм, взятых и так из огромного числа книг, окажутся случаи повторения, к этому никто не должен быть строг: скорее это следует отнести, во-первых, на счет человеческой слабости как части нашей натуры... Также следует иметь в виду, что существуют некоторые чрезвычайно краткие нормы, в которых повторение можно допустить ради благой цели... Что касается любых противоречий, встречающихся в этой книге, ни одно из них не имеет никаких притязаний на место в ней; никаких противоречий и не будет найдено, если мы полностью рассмотрим основания разночтений; будет найдена какая-нибудь особая отличительная черта, какой бы неопределенной она ни была, которая покончит с обвинением в непоследовательности, придаст другой вид вопросу и охранит его от обвинений в расхождении во мнениях» [Const. Tanta, 13; 15]. Constitutio Tanta также подчеркивала, что на создание Кодекса Феодосия II ушло десять лет, а на составление Дигест только три [Const. Tanta, 12].

В 534 г. Комиссия Трибониана переиздала Кодекс. Хотя работа над «Дигестами», без сомнения, была самой трудоемкой из когда-либо предпринятых в мировой юридической практике, новое издание Кодекса тоже влекло за собой большие усилия по реорганизации гражданских отношений и административных подходов. Теперь Кодекс (534) базировался на Дигестах (533) и Институциях (533).

В Дигестах были сосредоточены фундаментальные правовые положения, согласно с которыми Империя должна была жить и действовать. Дигесты заняли близкое к Основному Закону положение. Каждое действие чиновника, судьи, адвоката и гражданина должно было согласовываться с доктриной, изложенной в Дигестах. Любая другая кодификация лишь проистекала из общей доктрины. Издание 534 г. продемонстрировало единство принципов Дигест и прагматического nринциna generalitas в Кодексе.

Система и проистекающее право: вместо выводов.

В 533-534 годах Велизарий предпринял поход против вандало-аланского Карфагенского королевства. Началась византийская православная реконкиста на Западе. Восстановление политического контроля римлян над своими древними провинциями требовало разработки новой юридической базы. Речь шла не только об интеграции Запада в публичное политическое пространство Востока, но также о совместной выработке действующего права. Армии Юстиниана Великого создавали новые условия и перспективы для имперского развития. Появлялось множество новых законодательных актов, изданных императором для регуляции общественной жизни новых провинций, для реоргани- зации налоговых сборов, для военных структур и государственных ведомств.

Дигесты (533) оформили принципы и доктринальные особенности права. Новые законы Юстиниана лишь следовали этим принципам. Впервые право превращалось в логическую последовательность. Один закон логически вытекал из другого и предоставлял нормативную диспозицию для третьего. Формировалась система нормативной взаимосвязанности. Законодательство становилось универсальным, теряя признаки реактивного решения индивидуальных потребностей.

В случаях, требующих локального подхода, император готовил документ под названием Прагматическая санкция, призванный обеспечить привилегии, амнистию, установление порядка на территории отдельных провинций. Так называемое «старое право» (ius vetus) теперь уходило в небытие. Формой общения императора с гражданами становились Эдикты, которыми император вводил в силу кодексы, нормы и понятия. Новые законы, по традиции времен западноримского домината (284-480), получили привычное нашему слуху название leges.

В 534 году началась работа над приведением новых leges Юстиниана в соответствие с текстами Кодекса $(529,534)$, Дигест (533), Институций (533). Каждое императорское решение или инициатива приводились в полное соответствие с текстами предыдущих кодификаций. Придворные юристы усиленно следили за соблюдением точности и логичности норм и формулировок. В будущем, собрание этих императорских leges, изданных им в момент наибольшего напряжения внешнеполитических усилий (534-565 гг.), получило название «Новеллы» - Novellae (Leges). Это собрание, после смерти Юстиниана (565 г.), стало существенным дополнением к трем системным кодификациям. Незначительная часть leges была посвящена рассмотрению и детализации норм Кодекса $(529,534)$. В большинстве императорских законов шла речь о введении новых норм и упразднении старых. Но говоря о времени Юстиниана Великого, нужно помнить, что Novellae не составляли отдельной книги или особого типа кодификации: «При жизни Юстиниана Новеллы публиковались отдельными законами и не были объединены в отдельный сборник. Это сделали позже. К нашему времени дошло три сборника Новелл, ни один из которых не имел официального характера» $[1$, с. 100]. Это значит, что Новеллы имели характер проистекающего права. Они ориентировались на действующие формы основных собраний законов.

Система римского права, реформированная и отредактированная по инициативе и при деятельном участии императора Юстиниана Великого (527-565), состояла из трех официальных изданий.

Первое - Codex Justinianus в двенадцати книгах $(529,534)$.

Второе - Institutiones в четырех книгах (533).

Tретье - Digesta (Pandectae) в 7 частях, 50 книгах, 432 титулах, 9123 фрагментах работ и высказываний древнеримских правоведов.

Четвертое издание имело характер неофициального сборника разнообразных законодательных постановлений и предписаний императора - Novellae (Leges) в 168 законах, опубликованных Юстинианом после 534 г. 


\section{та міжнародно-правової науки}

Полное собрание из четырех групп книг в XII в., благодаря западноевропейским схоластам-правоведам, получило известное определение - Corpus Juris Civilis.

\section{Литература}

1. Балух В.О. Візантиністика : курс лекцій. Чернівці : Книги-XXI, 2006. 606 с.

2. Браччіні Т. Пізньоантична Італія і так званий кінець античного світу. Історія європейської цивілізації. Рим. / За ред. У. Еко. Харків : Фоліо, 2017. С. 211-214.

3. Графский В. Г. Всеобщая история права и государства. Москва : Норма, 2007. 752 с.

4. Ермолова И.Е. Римляне и гунны. Цивилизация и варварство. 2014. № 3. С. 215-221.

5. Кирилюк Ф.М. Неопатримоніалізм: історія, теорія, практика. К.: «Вадекс», 2014. 553 с.

6. Ле Гофф Жак. Рождение Европы. Серия «Становление Европы» / Пер. с фр. А.И. Поповой. Предисл. А.О. Чубарьяна. Санкт-Петербург: «Александрия», 2014. 398 с.

7. Мельник В.М. Теория симфонии в горизонтальном и вертикальном измерениях как политико-антропологическая черта Византийской истории. Гілея: науковий вісник : збірник наукових праць. 2017. Вип. 127 (12). С. 391-395.

8. Мельник В.М. Византия, германцы и славяне у истоков международной правосубъектности государств: римское юридическое наследие и проблема историческо- го неравенства возможностей. Аннали юридичної історії. 2017. T. 1. № 2. С. 59-92.

9. Норвич Д. История Византии. История Венецианской республики. Москва : АСТ: Астрель, 2011. 960 с.

10. Победоносцев К.П. Государство и Церковь. Сост., предисл., коммент. О.А. Суржик. Москва, 2011. Т. 1. 704 с.

11. Рябцева М.Л. Федераты позднеримской империи (по материалам письменных источников V-VI вв.). Научные ведомости Белгородского государственного университета. Серия: История, политология. 2016. Т. 40. № 22 (243). C. 62-66.

12. Хизер Питер. Восстановление Римской империи. Реформаторы Церкви и претенденты на власть. Москва : Центрполиграф, 2015. 575 с.

Мельник В. М., ассистент кафедры политологии Киевского национального университета имени Тараса Шевченко, преподаватель кафедры философии и общественных наук Винницкого национального медицинского университета имени Н. И. Пирогова, главный редактор научного журнала

«Анналы юридической истории», член Американского общества юридической истории 